\title{
Low frequency of HLA DRB1*03 - DQB1*02 and DQB1*0302 haplotypes in Romania is consistent with the country's low incidence of Type I diabetes
}

\author{
C. Ionescu-Tîrgoviste ${ }^{1}$, C. Guja ${ }^{1}$, M.Herr ${ }^{2}$, F. Cucca ${ }^{3}$, K. Welsh ${ }^{4}$, M. Bunce ${ }^{4}$, S. Marshall ${ }^{4}$ and J. A.Todd ${ }^{2}$ \\ ${ }^{1}$ Diabetes Clinic, Institute of Diabetes, Nutrition and Metabolic Diseases “N. Paulescu”, Bucharest, Romania \\ ${ }^{2}$ Wellcome Trust Centre for Molecular Mechanisms in Disease, Cambridge, UK \\ ${ }^{3}$ Department of Biomedical and Biotechnological Science, University of Cagliari, Italy \\ ${ }^{4}$ Tissue Typing Laboratory, Oxford Transplant Centre, Oxford, UK
}

\section{Abstract}

Aims/hypothesis. Our study aimed to determine the association of HLA class II $H L A-D Q B 1$ alleles with Type I (insulin-dependent) diabetes mellitus and the frequencies of these alleles in the Romanian population, which has one of the lowest incidences of Type I diabetes in children aged 0-14 years in Europe at 3-4 cases per 100000 person-years.

Methods. We used the sequence specific primer-polymerase chain reaction (PCR-SSP) technique to type $H L A-D Q B 1$ alleles, the $H L A-D R B 1$ alleles DRB $1 * 03$ and one single nucleotide polymorphism (SNP) in the insulin gene (INS). We studied 204 Type I diabetic Romanian families, 196 of which were simplex with $70.3 \%$ of subjects diagnosed under 14 years of age. Data was analysed using a modified version of the Transmission Disequilibrium Test, the Transmission Disequilibrium Test itself, and the affected family-based control method.

Results. We found, as expected, the strong positive DQB1*02-DRB1*03 and DQB1*0302, and negative
DQB1*0602, HLA class II allele associations with Type I diabetes in these Romanian families. However, using the affected family-based control method, we found relatively low population frequencies of DQB1*02-DRB1*03 and DQB1*0302 alleles in Romania $(15.8 \%)$ compared with Sardinia $(31.3 \%)$, a high incidence European region (35 cases per 100000 person-years in children aged 0-14 years). The INS locus had a strong effect in this data set with $80.5 \%$ transmission of the susceptible INS allele from parents to affected siblings (relative risk $=4.1$ ). Conclusion/interpretation. Part of the explanation for the low incidence of Type I diabetes in Romania could be the lower frequency of the DRB $1 * 03-$ DQB1*02 and DQB1*0302 susceptibility haplotypes in this country. [Diabetologia (2001) 44 [Suppl 3]: B 60-B 66]

Keywords Diabetes, $H L A D Q B 1, I N S$-VNTR, genetics, AFBAC frequency, Romania.
Type I (insulin-dependent) diabetes mellitus or primary insulin dependent diabetes mellitus (IDDM) is

Corresponding author: C. Ionescu-Tîrgoviste $\mathrm{MD}, \mathrm{PhD}$, Clinic of Diabetes, Institute of Diabetes, Nutrition and Metabolic Diseases "N. Paulescu", Str. I. Movila 5-7, Bucharest 2, Romania, E-mail: nbmetab1@sunu.rnc.ro

Abbreviations: MHC, Major histocompatibility complex; PCR-SSP, polymerase chain reaction-sequence specific primers; SNP, single nucleotide polymorphism; VNTR, variable number of tandem repeats, CTLA4, cytotoxyc T lymphocyte associated antigen 4; TDT, transmission disequilibrium test; PETDT, pairwise extended transmission disequilibrium test; AFBAC, affected family-based control. a common chronic autoimmune disease resulting from a $\mathrm{T}$ lymphocyte-mediated destruction of insulin-secreting pancreatic beta cells in genetically predisposed individuals. The almost complete destruction of beta cells results in total insulin dependency. The incidence of Type I diabetes in children and adolescents varies widely between different ethnic groups and even within ethnic groups from $3-45$ cases per 100000 person-years in Caucasians with a maximum of 45 cases per 100000 person-years in 1996 in Finnish children younger than 14 years [1-4]. One of the lowest incidence rates of Type I diabetes in children in Europe is in the Romanian population 
with less than 4 cases per 100000 person-years [4,5]. The role of genes in Type I diabetes is essential but the penetrance of susceptibility or resistance alleles is greatly influenced by environmental factors which have not yet been identified. Diet and infection are likely sources $[6,7,8,9,10]$.

Two susceptibility genes for Type I diabetes have been identified. The first is IDDM 1, encoded within the HLA region of the Major Histocompatibility Complex (MHC) on chromosome 6p21, and mapped to the HLA-DRB1, $-D Q B 1$ and $-D Q A 1$ loci [11-16]. Allelic variation of the exon 2 sequences of these genes probably accounts for the vast majority of the effect of $I D D M 1$. The second is IDDM 2, which has been mapped to the insulin gene region on chromosome $11 \mathrm{p} 15[17,18]$. The IDDM 2 is probably the variable number of tandem repeats (VNTR) locus 5' of the insulin gene [19]. The association of a third region, IDDM 12, close to the CTLA4 locus on chromosome $2 \mathrm{q}$, has been established, at least in some populations but the polymorphism responsible for this association has not yet been identified [20,21]. Other regions of the human genome have been linked to Type I diabetes but none of these putative disease genes has been identified $[22,23,24]$.

The incidence of Type I diabetes in Romania is one of the lowest in Europe [4,5]. Until now, no typing for Type I diabetes susceptibility genes in the Romanian population has been undertaken. Our study aimed to evaluate the IDDM 1 (HLA-DQB1 alleles and an allele of $D R B 1, \mathrm{DRB} 1 * 03)$ and IDDM 2 (INS -23 HphI Single Nucleotide Polymorphism (SNP)) status in a large group of Type I diabetic Romanian patients. Using a family study approach, we typed 204 Romanian Type I diabetic families by employing a single-protocol method of genotyping for multiple HLA and non-HLA polymorphisms under identical conditions, with the SSP-PCR technique $[25,26,27]$. To compare results, we used data from another group of families with Type I diabetes from Sardinia [28], a "hot spot" in incidence on the European map $[1,2]$.

\section{Subjects and methods}

Families. In this study 204 Romanian Type I diabetic families from all over Romania (Bucharest region and 12 other districts) were genotyped. Informed consent was obtained from all subjects involved before collection of blood for DNA extraction. The study was approved by the local ethics committee. Families were identified in the Bucharest "N.C. Paulescu" Institute outpatient department and in the diabetes centres of the other 12 Romanian districts. The selection of diabetic subjects was made according to the guidelines of EURODIAB epidemiological study protocol, that is those cases that had an abrupt onset with diabetic ketoacidosis or required insulin treatment with first insulin dose within the first month from diagnosis were diagnosed as having Type I diabetes [2]. Families were selected if both parents were alive and willing to participate in the study. Most families (196) were simplex families (i.e. only one child was affected) but 3 were multiplex families (i.e. at least 2 siblings were affected) and 5 families had a parent/sibling pair affected. A total of 144 families were fourmember families and the remaining 60 were three-member families. Overall the study group consisted of 756 individuals with $49.1 \%$ (371) being males and $50.9 \%$ (385) females. The patient cohort consisted of 212 Type I diabetic patients (106 males and 106 females) with the onset of disease between 9 months and 43 years of age. The mean age at the onset of disease was $12.1 \pm 6.7$ years. In most patients the onset of diabetes was before 17 years of age $(166 ; 78.3 \%)$ and the vast majority (149 out of $212 ; 70.3 \%$ ) had the onset before 14 years of age, consistent with the EURODIAB selection criteria [2]. Some of the subjects were therefore included in the EURODIAB epidemiological study between 1988-1997. There were 544 unaffected subjects (parents and unaffected siblings), 265 males $(48.7 \%) 279$ females $(51.3 \%)$.

The 257 Sardinian families were all single subject families, except for 13 who had a parent affected and 10 who had a second sibling affected [28]. In the Sardinian families HLA typing was performed as described previously [28].

Selection of genes. In this study all individuals were typed for class II $H L A-D Q B 1$ alleles at high resolution and for the $D R B 1$ allele DRB1*03. For the $H L A-D Q B 1$ locus, we typed for HLA $D Q 2$ (DQB1*02), DQ4 (DQB1*04), DQ5 (DQB1*05), DQ6 (DQB1*0601, *0602, *0603,*0604-9), $D Q 7$ (DQB1*0301,*0304), DQ8 (DQB1*0302) and $D Q 9$ (DQB1*0303,*03032) alleles. The DRB1*03 allele was typed to permit assignment of DQB1*0201 alleles to the DR3 haplotype, because the DRB1*03 and DQB1*0201 alleles are in almost complete linkage disequilibrium in the white European populations. Of note, the DQB $1 * 02$ - DRX assignment is an allele that is not the DRB1*03 haplotype but $D R 7$ or some other allele. In most European countries DQB $1 * 02$ alleles are usually found on the $D R 3$ or $D R 7$ haplotypes. We also typed one SNP of INS (chromosome 11p15): the -23 HphI A/T substitution [19]. The VNTR, an array of 14-15 bp oligonucleotide sequences, has over 30 alleles but they cluster in two main length classes, denoted class I for up to 45 repeats and class III for over 200 repeats. The class I allele is in almost complete linkage disequilibrium with the "A" allele of the SNP at the $-23 H p h I$ site of INS, and homozygosity of this class (or the -23 INS SNP) is associated with an odds ratio of 2-3 for Type I diabetes in white European populations [19,29].

DNA extraction. DNA was extracted from fresh peripheral EDTA anti-coagulated blood. We left $10 \mathrm{ml}$ of EDTA anti-coagulated blood to settle on the bench for $1 \mathrm{~h}$ and then the plasma was discarded or stored at $-80^{\circ} \mathrm{C}$. The remaining blood was mixed with Lysis buffer (109.5 g of Sucrose, $10 \mathrm{~g}$ of Triton-X$100,1.02 \mathrm{ml}$ of $4.9 \mathrm{~mol} / 1 \mathrm{MgCl}_{2}, 1 \mathrm{ml}$ of $1.0 \mathrm{~mol} / 1 \mathrm{TRIS}-\mathrm{HCl}$, $\mathrm{pH} 7.4$ up to 11 with double distilled water) up to a total volume of $40 \mathrm{ml}$. The mixture was centrifuged for $15 \mathrm{~min}$ at 2500 $\mathrm{rev} / \mathrm{min}$ at room temperature and the supernatant was discarded. The pellet was re-suspended in $20 \mathrm{ml}$ Lysis Buffer by vigorously mixing the tube to ensure the pellet was completely homogenised before being centrifuged for $15 \mathrm{~min}$ at $2500 \mathrm{rev} /$ min. After discarding the supernatant, DNA was extracted from this white blood cell pellet by adding to the pellet consecutively $3.5 \mathrm{ml}$ of $6 \mathrm{~mol} / \mathrm{l}$ guanidine hydrochloride, then $0.25 \mathrm{ml}$ of $7.5 \mathrm{~mol} / \mathrm{l}$ ammonium acetate and finally $0.25 \mathrm{ml}$ of $20 \%$ sodium N-lauroyl-sarcosinate. The tube was vortexed after each step until the pellet had dissolved. The pellet was incubated with $50 \mu \mathrm{l}$ of $10 \mathrm{mg} / \mathrm{ml}$ Proteinase $\mathrm{K}(\mathrm{BDH} 390373 \mathrm{P})$ at $37{ }^{\circ} \mathrm{C}$ 
over night. The tube was left to cool to room temperature and then $2 \mathrm{ml}$ of chloroform were added and the tube vortexed thoroughly followed by centrifugation for $3 \mathrm{~min}$ at $2500 \mathrm{rev} /$ min. The upper layer (DNA phase) was collected and added to $10 \mathrm{ml}$ of absolute ethanol and chilled at $-20^{\circ} \mathrm{C}$ for $1 \mathrm{~h}$. The tube was gently inverted to precipitate the DNA and then centrifuged for $15 \mathrm{~min}$ at $3000 \mathrm{rev} / \mathrm{min}$ at room temperature to pellet the DNA. Finally, the DNA pellet was washed in $4 \mathrm{ml}$ of $70 \%$ ethanol and centrifuged at $3000 \mathrm{rev} / \mathrm{min}$ for $5 \mathrm{~min}$. The ethanol was poured off and the pellet left to dry for 1-2 $\mathrm{h}$ at room temperature. We added $300 \mu \mathrm{l}$ of TE buffer $\mathrm{pH} 7.5$ ( $1 \mathrm{ml}$ of $1 \mathrm{~mol} / \mathrm{l}$ TRIS, pH7.5, $20 \mu \mathrm{l}$ of $0.5 \mathrm{~mol} / \mathrm{l}$ EDTA, up to $100 \mathrm{ml}$ with double distilled water) to the pellet which was then placed at $4^{\circ} \mathrm{C}$ until fully re-suspended. The DNA was quantified using PicoGreen double stranded DNA (dsDNA) Quantitation Reagent (Molecular Probes).

Primer design. All listed primers are 5' to 3'. PCR primers for $H L A-D Q B 1$ allele analysis were as previously described $[25,27]$. The sequences of the primers used for typing of the -23 HphI A/T polymorphism were (Genebank accession number J00265): T allele forward primer CCTCAgCCCTgCCTgTCT (annealing position 2384-2401); reverse primer gACgTgACCAAgAgAACTTC (annealing position 2761-2742), $100 \mathrm{ng} / \mathrm{PCR}$ amplification, $378 \mathrm{bp}$ amplicon; A allele forward primer CCTCAgCCCTgCCTgTCA (annealing position 2384-2401); reverse primer gACgTgACCAAgAgAACTTC (annealing position 2761-2742), $100 \mathrm{ng} / \mathrm{PCR}$ amplification, 378 bp amplicon. For both alleles we used an internal control to validate amplification: $H L A-D R B 1$ intron 3 amplicon of $796 \mathrm{bp}$, forward primer TgCCAAgTggAgCACCCAA with annealing position exon 3 amino acid 173-179; reverse primer gCATCTTgCTCTgTgCAgAT with annealing position in exon 4 amino acid 193-200, both $12 \mathrm{ng} / \mathrm{PCR}$ amplification. The primers used for DRB1*03 alleles amplification were: $D R 3$ forward primer 1 TACTTCCATAACCAGGAGGAGA, $D R 3$ forward primer 2 TTCCATAACCAGGAGGAGTC, DR3 reverse primer 1 GTCCACCCGGCCCCGCT. We used the same primers for the internal control product as for INS-HphI typing.

PCR amplification and electrophoresis. PCR amplification and electrophoresis for $H L A-D Q B 1$ and INS-HphI alleles was performed as previously described [25,26,27]. Genomic DNA was amplified in $13 \mu \mathrm{g}$ reactions. For each PCR, the reaction mix consisted of base buffer (67 mmol TRIS base $\mathrm{pH} 8.8$, $16.6 \mathrm{mmol}$ ammonium sulphate; $0.01 \% \mathrm{v} / \mathrm{v}$ Tween); $2 \mathrm{mmol}$ magnesium chloride; $200 \mathrm{mmol}$ of each of dATP, dGTP, dCTP and dTTP; 0.1875 units of Taq polymerase (Advanced Biotechnology, London, UK) and between 40-60 ng DNA. DNA was briefly mixed with the buffer [26] and $8 \mu$ of DNA/buffer mix was aliquoted onto $5 \mu \mathrm{l}$ primer mix. All the reactions were performed under $10 \mu \mathrm{l}$ mineral oil (Sigma, Dorset, UK) in 96 well PCR plates (Advanced Biotechnology). The DNA samples were amplified in MJ Research PTC-200 or GeneAmp 9600 PCR system (Perkin-Elmer Corporation, Calif., USA) thermal cyclers. The PCR plates were previously sealed with thermowell sealers (Costar, Buckinghamshire, UK) and dipped in mineral oil in order to improve plate-to-block contact during amplification. The cycling parameters were $1 \mathrm{~min}$ at $96^{\circ} \mathrm{C}$ followed by 5 cycles of $96^{\circ} \mathrm{C}$ for $25 \mathrm{~s}, 70^{\circ} \mathrm{C}$ for $45 \mathrm{~s}$ and $72^{\circ} \mathrm{C}$ for $45 \mathrm{~s}$, followed by 21 cycles of $96^{\circ} \mathrm{C}$ for $25 \mathrm{~s}, 65^{\circ} \mathrm{C}$ for $50 \mathrm{~s}$ and $72^{\circ} \mathrm{C}$ for $45 \mathrm{~s}$, followed by 4 cycles of $96^{\circ} \mathrm{C}$ for $25 \mathrm{~s}, 55^{\circ} \mathrm{C}$ for $60 \mathrm{~s}$ and $72^{\circ} \mathrm{C}$ for $120 \mathrm{~s}$. After PCR, $5 \mu \mathrm{l}$ of loading buffer $(0.25 \%$ Orange G, $30 \%$ v/v glycerol and $0.5 x$ TBE buffer TRIS/Boric acid/EDTA) was added to each reaction mix.

Subsequently, PCR products were electrophoresed through $1 \%$ agarose gels containing $0.5 \mu \mathrm{g} / \mathrm{ml}$ ethidium bromide in
0.5xTBE buffer ( $89 \mathrm{mmol}$ TRIS base, $89 \mathrm{mmol}$ boric acid, $2 \mathrm{mmol}$ EDTA, pH 8.0) for 20-30 min at $15 \mathrm{~V} / \mathrm{cm}$. Following electrophoresis, the products were visualised with UV illumination and the gel photographed with a Polaroid camera. Gel interpretation was simple and done according to the presence or absence of an amplicon. For validation of PCR amplification, all reactions included an internal control, a 796 or $256 \mathrm{bp}$ product depending on the HLA amplicon size, as described previously [25,26,27].

The HLA-DRB1*03 allele was also typed using PCR-SSP under the following assay conditions: Genomic DNA was amplified in $13 \mu \mathrm{l}$ reactions each comprising of $3 \mu \mathrm{l}$ primer mix (2500 ng forward primer 1 and 2, $2500 \mathrm{ng}$ reverse primer 1 and $750 \mathrm{ng}$ of each of the internal control primers in a total volume of $300 \mu \mathrm{l}$ made up to $3 \mu \mathrm{l}$ with double distilled water) and $5 \mu \mathrm{l}$ of $2 \mathrm{mmol} / \mathrm{l}$ TDMH (2.6 X buffer (Bioline) and $0.48 \mathrm{mmol}$ of each of dATP, dGTP, dCTP and dTTP, and $5.2 \mathrm{mmol} \mathrm{MgCl}_{2}$ in a total volume of $1 \mathrm{ml}$ made up with double distilled water) and $0.06 \mu \mathrm{l}$ BioTaq (Bioline) added to $5 \mu \mathrm{l}$ DNA at $4 \mathrm{ng} / \mu \mathrm{l}$. The reactions were performed in 96 well PCR plates (AB Gene, Surrey, UK) and plates were sealed with $0.2 \mathrm{ml}$ micro-Caps (AB Gene, Surrey, UK). The DNA samples were amplified in MJ Research PTC-225 thermal cyclers. The cycling parameters were $1 \mathrm{~min}$ at $96^{\circ} \mathrm{C}$ followed by 5 cycles of $96^{\circ} \mathrm{C}$ for $20 \mathrm{~s}, 70^{\circ} \mathrm{C}$ for $45 \mathrm{~s}$ and $72^{\circ} \mathrm{C}$ for $25 \mathrm{~s}$, followed by 21 cycles of $96^{\circ} \mathrm{C}$ for 25 s, $65^{\circ} \mathrm{C}$ for $50 \mathrm{~s}$ and $72^{\circ} \mathrm{C}$ for $30 \mathrm{~s}$, followed by 4 cycles of $96^{\circ} \mathrm{C}$ for $30 \mathrm{~s}, 55^{\circ} \mathrm{C}$ for $60 \mathrm{~s}$ and $72^{\circ} \mathrm{C}$ for $120 \mathrm{~s}$. After PCR, $5 \mu \mathrm{l}$ of loading buffer was added to each reaction mix and the PCR products were electrophoresed through a $3 \% \mathrm{v} / \mathrm{v} 1.5 \%$ agarose and $1.5 \%$ Nusieve gel in $1 \mathrm{xTBE}$ buffer until bands in the $100-300$ bp range were clearly resolvable. The products were visualised with UV illumination and the gel photographed. The gel was scored for the presence or absence of a $151 \mathrm{bp}$ amplicon. For validation of PCR amplification, all reactions included the 796 bp internal control product.

Data analysis. Data were initially analysed using the Transmission Disequilibrium Test (TDT) [30]. The TDT tests the possibility that transmission of alleles from heterozygous parents to affected siblings is not the expected $50 \%$. The TDT relative risk (RR) was calculated by dividing the number of times an allele was transmitted by the number of times it was not transmitted. Only alleles that were common enough to occur in 10 or more heterozygous parents were included. An alternative, but related, test is the affected family-based control (AFBAC) approach which assembles controls from the parental alleles not transmitted to affected siblings (or never transmitted in an affected sib-pair family) [31,32]. Allele and haplotype frequencies in these artificial controls are unbiased estimates of the frequencies in the general population from which the families were ascertained [31]. The AFBAC method requires that alleles are in Hardy Weinberg equilibrium (HWE), and does, to some extent, control for the genetic mismatching of patients and control subjects that can occur if control subjects are simply selected from the population as healthy volunteers [31]. All tested $H L A-D Q B 1$ alleles and the two alleles of INS $23 \mathrm{Hph}$ locus were in Hardy-Weinberg Equilibrium in the analysed families. All $p$ values of less than 0.05 were noted.

The third method we used was a modified version of the extended TDT (ETDT) [33] referred to as the pairwise ETDT (PETDT) [34]. The PETDT estimates a Relative Transmission Probability (RTP) for each $D Q B 1$ allele or haplotype compared to one fixed haplotype or allele. In the present report the $D Q B 1$ allele often associated with the $D R 1$ haplotype, DQB1*05 was chosen as the reference haplotype. The DQB1*05 allele or haplotype is generally accepted as having a neutral effect in Type I diabetes and hence the application 
Table 1. Transmission of $H L A-D Q B 1$ alleles to affected children in Romanian families (TDT results), their AFBAC population frequencies and the results of PETDT analysis

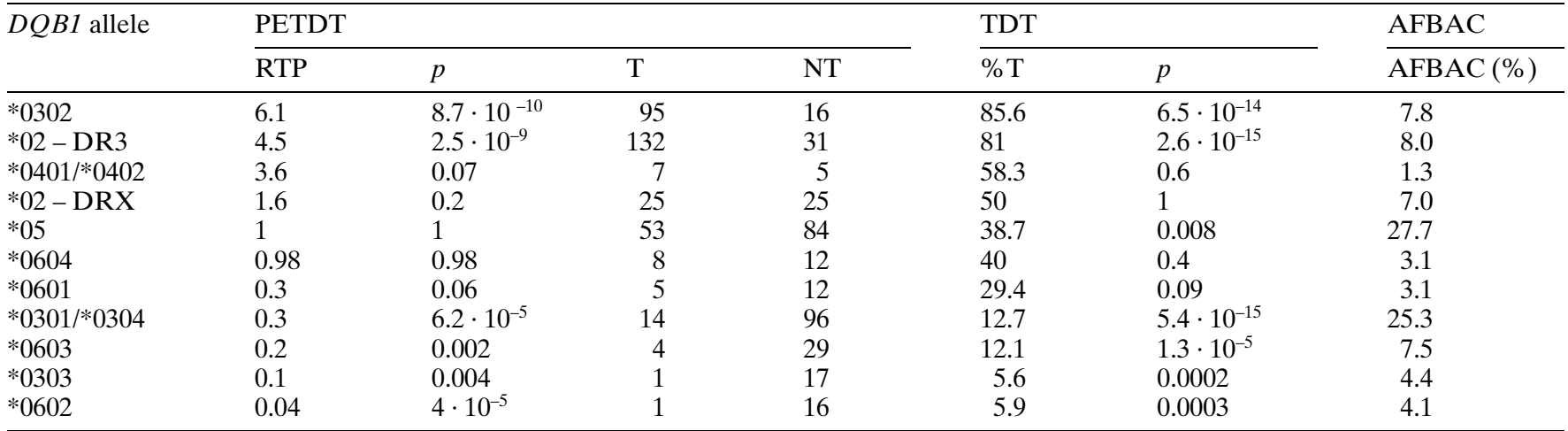

RTP = Relative Transmission Probability; $\mathrm{T}=$ Transmitted; NT = Not transmitted; \% $\mathrm{T}=$ Transmission percentage; AFBAC $(\%)=$ allele frequency estimated by AFBAC method

Table 2. Transmission of $H L A-D Q B 1$ alleles to affected children in Sardinian families (TDT results), their AFBAC population frequencies and the results of PETDT analysis

\begin{tabular}{|c|c|c|c|c|c|c|c|}
\hline \multirow[t]{2}{*}{$D Q B 1$ allele } & \multicolumn{4}{|c|}{ PETDT } & \multicolumn{2}{|c|}{ TDT } & \multirow{2}{*}{$\frac{\mathrm{AFBAC}}{\operatorname{AFBAC}(\%)}$} \\
\hline & RTP & $p$ & $\mathrm{~T}$ & NT & $\% \mathrm{~T}$ & $p$ & \\
\hline$* 0302$ & 5.7 & $1.1 \cdot 10^{-11}$ & 88 & 32 & 73.3 & $3.2 \cdot 10^{-7}$ & 8.7 \\
\hline *02 (DR4) & 2.6 & 0.1 & 6 & 8 & 42.9 & 0.6 & 1.6 \\
\hline$* 05$ & 1 & 1 & 46 & 140 & 24.7 & $5.5 \cdot 10^{-12}$ & 35.3 \\
\hline *02 - DR7 & 0.7 & 0.5 & 6 & 21 & 22.2 & 0.004 & 4.2 \\
\hline *0301 & 0.2 & $2.9 \cdot 10^{-5}$ & 9 & 108 & 7.7 & $5.6 \cdot 10^{-20}$ & 21.8 \\
\hline
\end{tabular}

RTP = Relative Transmission Probability; T = Transmitted; NT = Not transmitted; \% $\mathrm{T}=$ Transmission percentage; AFBAC $(\%)=$ allele frequency estimated by AFBAC method

of the PETDT allows haplotypes to be distinguished that are significantly more or less predisposing than DQB1*05 haplotypes. The null hypothesis is that the two haplotypes have the same relative risk. The RTP values give a clear indication of which alleles are predisposing and which alleles are protective, rather than neutral. In other words the PETDT ensures that allele are not classified as negatively associated with disease or protective, for example, simply because the other common alleles in the parents were highly susceptible DQB1*02 DRB $1 * 03$ or DQB $1 * 0302$ alleles.

With 204 families, we had $80 \%$ statistical power to detect an odds ratio of 2 or greater at $p=0.0001$ for a disease locus with minor allele frequency of 0.3 or greater. Because the odds ratios for certain alleles at $H L A$ and at INS are greater than 2, we were confident this could replicate previous Type I diabetes associations at these loci.

\section{Results}

Table 1 shows the TDT, PETDT and AFBAC results for $11 H L A-D Q B 1$ alleles in 204 Type I diabetic Romanian families. For comparison, in Table 2 we show the results of the same tests for 6 alleles in 257 Sardinian families (the other 5 alleles were too rare in the Sardinian sample to be considered). Compared with $\mathrm{DQB} 1 * 05$, the predisposition of the DQB $1 * 0302$ and DQB1*02-DRB1*03 alleles is the same in this
Romanian sample as in the Sardinian families with RTP values of between 4 and 6 . That is, in Romanian and in Sardinian simplex families the *0302 and *02DRB1*03 alleles are 4 to 6 times more predisposing than the DQB1*05 allele $\left(p<10^{-8}\right)$. These two alleles, $* 0302$ and $* 02-$ DRB $1 * 03$ are transmitted $86 \%$ and $81 \%$ to affected siblings and have odds ratios from the TDT transmission data of 5.9 and 4.3, respectively (Table 1) compared to $73 \%$ and $82 \%$ transmission in the Sardinian families (Table 2). In the Romanian families, 5 alleles are less predisposing, that is protective, than allele DQB $1 * 05(p<0.005)$ : $* 0301 / * 0304, * 0603, * 0303$, and $* 0602$, all DQ $\beta$-chain Asp57 encoding alleles [14]. For example, the RTP value for $* 0602$ was 0.04 , in other words, *0602 is 25 times less predisposing in this data set than allele DQB1*05 $(p=0.00004)$. Allele DQB1*0602 is very rare in Sardinians but it is to be noted that the DQB1*0301 allele is equally protective in both populations and about four times less predisposing than DQB1*05 allele (Tables 1 and 2).

Importantly, all alleles, except DQB1*0303, were transmitted to unaffected Romanian siblings at a percentage transmission not very different from the expected $50 \%$ (Table 3 ). For DQB $1 * 0303$ the sample size was very small (10 transmitted and 1 not trans- 
Table 3. Transmission of $H L A-D Q B 1$ alleles to unaffected siblings in Romanian families (TDT results)

\begin{tabular}{lrrll}
\hline DQB1 allele & \multicolumn{2}{l}{ TDT } & & \\
\cline { 2 - 5 } & $\mathrm{T}$ & $\mathrm{NT}$ & $\% \mathrm{~T}$ & $p$ \\
\hline$* 0302$ & 27 & 40 & 40.3 & 0.1 \\
$* 02-\mathrm{DR} 3$ & 58 & 54 & 51.8 & 0.7 \\
$* 0401 / * 0402$ & 6 & 4 & 60 & 0.5 \\
$* 02-\mathrm{DRX}$ & 18 & 15 & 54.5 & 0.6 \\
$* 05$ & 41 & 43 & 48.8 & 0.8 \\
$* 0604$ & 7 & 9 & 43.8 & 0.6 \\
$* 0601$ & 6 & 2 & 75 & 0.2 \\
$* 0301 / * 0304$ & 37 & 40 & 48.1 & 0.7 \\
$* 0603$ & 10 & 10 & 50 & 1 \\
$* 0303$ & 10 & 1 & 90.9 & 0.007 \\
$* 0602$ & 6 & 5 & 54.5 & 0.8 \\
\hline
\end{tabular}

$\mathrm{T}=$ Transmitted, NT = Not transmitted; \% $\mathrm{T}=$ Transmission percentage

mitted; $p=0.007$ ) and the apparent positive transmission to unaffected siblings will have to be re-evaluated in a larger data set.

Therefore, it appears that the relative susceptibility or protection of $H L A-D Q B 1$ alleles is not different between the two countries, even though they have vastly different population incidences of Type I diabetes. Interesting then are the AFBAC data which indicate that the general population frequencies of the DQB1*0302 and DQB1*02 - DRB1*03 alleles are lower in Romania than in Sardinia, $15.8 \%$ versus $31.3 \%$ (Tables 1 and 2 ).

Finally, the INS -23 HphI SNP data were analysed and a very strong association of the A allele or, conversely, a negative or protective effect of the T allele was observed in Romanian families (Table 4). At $80.6 \%$ transmission $(\mathrm{RR}=4.2)$ this is the same predisposition as the HLA-DQB1 alleles *02 DRB $1 * 03$ or $* 0302$. Transmission of the A allele to unaffected siblings was not noticeably different than $50 \%(45.8 \%)$. The AFBAC control frequency was $77 \%$ for the A allele, not noticeably different than that observed in other European countries e.g. $72.7 \%$ in the UK and $79.2 \%$ in Sardinia (Table 4), where the percentage transmission of the A allele is lower at $61.9 \%$ and $62.4 \%$, respectively [19].

\section{Discussion}

Romania has one of the lowest incidences of Type I diabetes in children and in adolescents in Europe. Three explanations are possible. Firstly, the Romanian environment such as diet or infection pattern is not permissive for the development of Type I diabetes. Secondly, the main susceptibility haplotypes bearing the most strongly disease-associated HLA$D Q B 1$ alleles, ${ }^{*} 0302$ and $* 02-\mathrm{DRB} 1 * 03$, are not as predisposing as non-Romanian *0302 and *02 DRB1*03 haplotypes because the Romanian haplotypes carry alleles at other MHC loci that lower their predisposition to Type I diabetes. Finally, the overall population frequencies of the $* 0302$ and $* 02-$ DRB1*03 haplotypes are lower in Romania than in countries with higher Type I diabetes incidence rates. Our data suggest that the third possibility is part of the explanation because the combined frequency of the $* 0302$ and $* 02-\mathrm{DRB} 1 * 03$ alleles is only approximately half $(15.8 \%)$ that of Sardinia, a high incidence country $(31.3 \%)$. For Sardinia, the AFBAC value of $31.3 \%$ is almost identical to the HLA alleles frequencies obtained from typing newborn children from Sardinia (F. Cucca, unpublished data). The AFBAC approach is further validated by comparison of AFBAC HLA-DQB1 allele frequencies from Type I diabetic affected sib-pair families and the allele frequencies from UK organ donors (J. A. Tood, K. Welsh, unpublished data). Interestingly, the AFBAC frequencies of $* 0302$ plus $* 02-\mathrm{DRB} 1 * 03$ in the UK (an intermediate incidence country at approximately 15 cases per100000 person-years) are higher than in Romania, at $19.3 \%$ (J. A. Tood, unpublished data). Calculating the AFBAC frequencies of $H L A$ alleles from several countries would throw light on any possible correlation between incidence and population frequency of $H L A$ susceptibility alleles. Previously, a correlation has been found between $H L A-D Q B 1$ alleles and population incidence of disease [35]. The relative frequency of protective alleles could also be a factor together with diet, and the level of infection. The role of diet, not addressed in this study, could well be a factor since the average diet in Sardinia and the UK can be expected, even today, to have a higher animal protein, fat and carbohydrate content than the diet in Romania. It will be interesting to see

Table 4. Transmission of INS-HphI alleles to affected children in Romanian and Sardinian families (TDT results) and their AFBAC population frequencies

\begin{tabular}{|c|c|c|c|c|c|c|}
\hline & \multicolumn{5}{|l|}{ TDT } & \multirow{2}{*}{$\frac{\text { AFBAC }}{\operatorname{AFBAC}(\%)}$} \\
\hline & INS-23HphI allele & $\mathrm{T}$ & NT & $\% \mathrm{~T}$ & $p$ & \\
\hline Romania & $\mathrm{A}$ & 83 & 20 & 80.6 & $5.4 \cdot 10^{-10}$ & 77.2 \\
\hline
\end{tabular}

$\mathrm{T}=$ Transmitted; $\mathrm{T}=$ Not transmitted; $\% \mathrm{~T}=$ Transmission percentage; AFBAC $(\%)=$ allele frequency estimated by AFBAC method 
if the incidence of Type I diabetes increases as the economy of Romania develops.

The other main finding of our study is the exceptionally strong association of the A allele of the INS $-23 H p h I$ SNP, which is an accurate marker for the INS VNTR locus believed to be the IDDM 2 locus. In our sample of Romanian families it was as predisposing as the most predisposing of $H L A-D Q B 1$ alleles. This result requires confirmation in a second independent set of Romanian families. The increased penetrance of the protective effect of the $\mathrm{T}$ allele, which is thought to be the relevant trait at the IDDM 2 locus, could be due to differences in the genetic background of the population at HLA or at other genes still to be identified. Or it could be due to changes in the environment that has increased the penetrance of the class III VNTR allele [19].

Another explanation could, however, be the existence of what has been designated as the Very Protective Haplotype (VPH) and the Protective Haplotype $(\mathrm{PH})$, each with a different subset of class III alleles [19]. We could not distinguish the VPH and PH using our methods. If class III alleles belong more often to the VPH group in this Romanian cohort, this could explain the higher transmission of class I alleles to affected offspring from class I/III heterozygous parents. This would make the study of the association of the VNTR class III alleles in Romanian Type II diabetes patients important, as these allele have been associated with predisposition to Type II diabetes, rather than protection from, Type II diabetes [36].

Our results show the potential value of studying the genetics and gene-environment interactions of Type I diabetes in a country with a low disease incidence.

Acknowledgements. We are very grateful to all the people who contributed to the collection of the families analysed in this paper: D. Avram, A. Babes, D. Catrinoiu, S. Constantinescu, J. Cristescu, G Creteanu, I Ferariu, M. Gavanescu, M. Graur, D. Lepadat, A. Minescu, M. Morosanu, M. Mota, R. Nicolescu, L. Predescu, M. Radulescu and M. Strugariu. Marilyn Merriman is especially thanked for her preparation of the DNA samples. We would like to thank S. Nutland for her assistance in preparing this manuscript. The study has been partially supported by the European Community Concerted Action EURODIAB TIGER (contracts BMH4-CT96-0577 and IC20-CT96-0070). M. Herr was a postdoctoral research fellow funded by the Juvenile Diabetes Research Foundation International (JDRFI). The Wellcome Trust, Diabetes UK, the Juvenile Diabetes Research Foundation are thanked for their financial support.

\section{References}

1. Karvonen M, Tuomilehto J, Libman I, LaPorte R (1993) A review of the recent epidemiological data on the worldwide incidence of Type I (insulin-dependent) diabetes mellitus. Diabetologia 36: 883-892

2. Green A, Gale EA, Patterson CC (1992) Incidence of childhood onset insulin-dependent diabetes mellitus: the EURODIAB ACE Study. Lancet 339: 905-909
3. Tuomilehto J, Karvonen M, Pitkäniemi J et al. (1999) Record-high incidence of Type I (insulin-dependent) diabetes mellitus in Finnish children. Diabetologia 42: 655-660

4. Ionescu-Tirgoviste C, Serban V, Guja C et al. (1999) Very low incidence of Type I diabetes in children in Romania. Diabetologia 42 [Suppl 1] A85 (Abstract)

5. Ionescu-Tirgoviste C, Paterache E, Cheta D, Farcasiu E, Serafinceanu C, Mincu I (1994) Epidemiology of Diabetes in Bucharest. Diabet Med 11: 413-417

6. Cudworth A, Woodrow J (1974) HL-A system and diabetes mellitus. Diabetes 24: 345-349

7. Todd JA (1991) A protective role of the environment in the development of Type I diabetes ? Diabet Med 8: 906-910

8. Kyvik KO, Green A, Beck-Nielsen H (1995) Concordance rates of insulin dependent diabetes mellitus: a population based study of young Dansih twins. BMJ 311: 913-917

9. Risch N (1987) Assessing the role of HLA-linked and unlinked determinants of disease. Am J Hum Genet 40: $1-14$

10. Olmos P, A'Hern R, Heaton DA et al. (1988) The significance of the concordance rate for Type I (insulin-dependent) diabetes in identical twins. Diabetologia 31: 747-750

11. Singal DP, Blajchman MA (1973) Histocompatibility antigens, lymphocytotoxic antibodies and tissue antibodies in patients with diabetes mellitus. Diabetes 22: 429-432

12. Nerup J, Platz P, Andersen OO et al. (1974) HLA antigens and diabetes mellitus. Lancet ii: $864-866$

13. Cucca F, Todd JA (1996) HLA susceptibility to Type I diabetes: methods and mechanisms. In: Browning $\mathrm{MJ}$, McMichael AJ (eds) HLA/MHC: Genes Molecules and Function. BIOS Scientific Publishers, Oxford, pp 383-405

14. Todd JA, Bell JI, McDevitt HO (1987) HLA-DQ beta gene contributes to susceptibility and resistance to insulin-dependent diabetes mellitus. Nature 329: 599-604

15. Sheehy MJ, Scharf SJ, Rowe JR et al. (1989) A diabetessusceptible HLA haplotype is best defined by a combination of HLA-DR and -DQ alleles. J Clin Invest 83: 830-835

16. Todd JA, Mijovic C, Fletcher J, Jenkins D, Bradwell AR, Barnett AH (1989) Identification of susceptibility loci for insulin-dependent diabetes mellitus. Nature 338: 587-589

17. Bell GI, Horita S, Karam JH (1984) A polymorphic locus near the human insulin gene is associated with insulin-dependent diabetes mellitus. Diabetes 33: 176-183

18. Hitman GA, Tarn AC, Winter RM et al. (1985) Type I (insulin-dependent) diabetes and a highly variable locus close to the insulin gene on chromosome 11. Diabetologia 28: 218-222

19. Bennett ST, Lucassen AM, Gough SCL et al. (1995) Susceptibility to human Type I diabetes at IDDM 2 is determined by tandem repeat variation at the insulin gene minisatellite locus. Nat Genet 9: 284-292

20. Nistico L, Buzzetti R, Pritchard LE et al. (1996) The $C T L A-4$ gene region of chromosome $2 \mathrm{q} 33$ is linked to, and associated with, Type I diabetes. Hum Mol Genet 5: $1075-1080$

21. Todd JA, Farrall M (1996) Panning for gold: genome-wide scanning for linkage in Type I diabetes. Hum Mol Genet 5: $1443-1448$

22. Todd JA, Bain SC (1992) A practical approach to identification of susceptibility genes for IDDM. Diabetes 41: 1029-1034

23. Risch N (1990) Linkage strategies for genetically complex traits: The power of affected relative pairs. Am J Hum Genet 46: 229-241

24. Todd JA (1995) Genetic analysis of Type I diabetes using whole genome approaches. Proc Natl Acad Sci USA 92: $8560-8565$ 
25. Bunce M, O’Neill CM, Barnardo MCNM et al. (1995) Phototyping: comprehensive DNA typing for HLA-A, B, C, DRB1, DRB3, DRB5 \& DQB1 by PCR with 144 primer mixes utilizing sequence-specific primers (PCR-SSP). Tissue Antigens 46: 355-367

26. Mullighan CG, Marshall SE, Bunce M, Welsh KI (1999) Variation in immunoregulatory genes determines the clinical phenotype of common variable immunodeficiency. Genes and Immunity 1: 137-148.

27. Bunce M (1996) The development and applications of a single PCR-based method of HLA genotyping. [PhD thesis], Oxford Brookes University, Oxford

28. Cucca F, Goy JV, Kawaguchi Y et al. (1998) A male-female bias in Type I diabetes and linkage to chromosome Xp in MHC HLA-DR3-positive patients. Nat Genet 19: 301-302

29. Bennett ST, Todd JA (1996) Human Type I diabetes and the insulin gene: principles of mapping polygenes. Annu Rev Genet 30: 343-370

30. Spielman RS, McGinnis RE, Ewens WJ (1993) Transmission test for linkage disequilibrium: the insulin gene region and insulin-dependent diabetes mellitus (IDDM). Am J Hum Genet 52: 506-516

31. Thomson G (1995) Mapping disease genes: family-based association studies. Am J Hum Genet 57: 487-498
32. Thomson G (1988) HLA disease associations: a model for the study of complex human genetic disorders. Annu Rev Genet 22: 31-50

33. Sham PC, Curtis D (1995) An extended transmission/disequilibrium test (TDT) for multi-allele marker loci. Ann Hum Genet 59: 323-336

34. Koeleman BPC, Dudbridge F, Cordell HJ, Todd JA (2000) Adaptation of the extended transmission/disequilibrium test to distinguish disease associations of multiple loci: the Conditional Extended Transmission/Disequilibrium Test. Ann Hum Genet 64: 207-213

35. Dorman JS, LaPorte RE, Stone RA, Trucco M (1990) Worldwide differences in the incidence of type I diabetes are associated with amino acid variation at position 57 of the HLA-DQ beta chain. Proc Natl Acad Sci USA. 87: 7370-7374

36. Huxtable SJ, Saker PJ, Haddad L et al. (2000) Analysis of parent-offspring trios provides evidence for linkage and association between the insulin gene and Type 2 diabetes mediated exclusively through paternally transmitted class III variable number tandem repeat alleles. Diabetes 49: 126-130 